2. Agarwal H., Kumar S.V., Rajeshkumar S. A review on green synthesis of zinc oxide nanoparticles - An eco-friendly approach. ResourceEfficient Technologies, 2017, V. 3, Is. 4, P. 406-413.

3. Araujo F.P., Trigueiro P., Honório L.M.C., et. al. A novel green approach based on $\mathrm{ZnO}$ nanoparticles and polysaccharides for photocatalytic performance. Dalton Trans., 2020, P. 1-11.

4. Praiboon J., Chirapart A., Akakabe Y., et. al. Physical and Chemical Characterization of Agar Polysaccharides Extracted from the Thai and Japanese Species of Gracilaria. ScienceAsia, 2006, V. 32, P. 11-17.

DOI https://doi.org/10.30525/978-9934-26-006-3-35

\title{
АЛКІЛЮВАННЯ КЕТЕНАМІНАЛЕЙ ІЗ ЗАСТОСУВАННЯМ УЛЬТРАЗВУКОВОГО ВИПРОМІНЮВАННЯ
}

\author{
Харченко Ю. В. \\ кандидат хімічних наук, \\ старший викладач кафедри хімії та методики навчання хімії \\ Сумський державний педагогічний університет імені А. С. Макаренка \\ м. Суми, Украӥна
}

Гетероциклічні кетенаміналі (ГКА), які можна також віднести до циклічних 1,1-єндиамінів, є універсальними проміжними сполуками в органічному синтезі. Цікавою особливістю цих сполук є їх будова. В молекулах кетенаміналей $є 4$ нуклеофільні центри: два атоми Нітрогену аміногруп, атом Оксигену карбонільної групи та $\alpha$-атом Карбону.

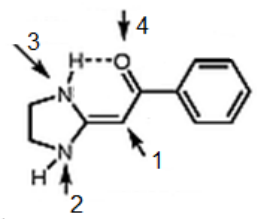

Супряження електроно-донорних аміногруп та електроноакцепторної карбонільної групи призводить до значного підвищення електронної густини на $\alpha$ - атомі Карбону та сильної поляризації подвійного зв'язку $\mathrm{C}=\mathrm{C}$, внаслідок чого нуклеофільність $\alpha$-атома Карбону набагато вища, ніж на атомах Нітрогену аміногруп. 
Внаслідок особливостей будови, ці сполуки $\epsilon$ високореакційноздатними. ГКА виступають бінуклеофілами, тому що крім $\alpha$ атома Карбону в реакцію може вступати і вторинна аміногрупа, а отже, при взаємодії з біелектрофілами можуть утворювати конденсовані гетероцикли різних типів, які важко отримати іншими синтетичними методами [1]. Специфічні хімічні властивості даного класу сполук викликають неабиякий інтерес у хіміків-синтетиків, тому хімія ГКА дуже активно розвивається.

Варто зазначити, що деякі ГКА та їх похідні також виявляють певну біологічну активність, що привернуло увагу хіміків та агрохіміків. Сполуки, які одержують на основі гетероциклічних кетенаміналей, часто проявляють себе як фармакофори, вони використовуються для синтезу лікарських засобів, пестицидів та в інших галузях, що стосуються біоактивних сполук [2].

Одним із напрямків модифікації ГКА $є$ реакція алкілювання. Як показали дослідження, алкілювання може проходити як по атому Карбону, так і по атому Нітрогену. При чому при проведенні взаємодії iз алкілюючими реагентами у більш жорстких умовах, реакція відбувається переважно як $\mathrm{N}$-алкілювання.

Зокрема при взаємодії із бензил хлоридом 2 залежно від умов проведення можуть утворюватися різні продукти 3 та 4 [3]:

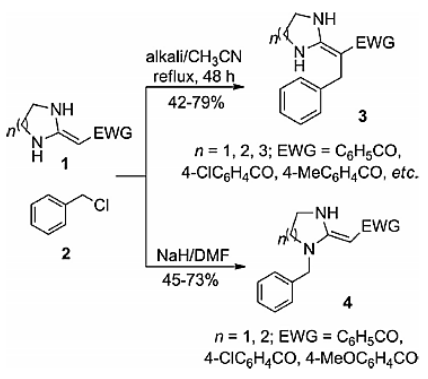

Взаємодія кетенаміналей 3 -бромокетонами призводить до утворення піролконденсованих 1,3-діазогетероциклів. В ході реакції гідроген бромід, який утворюється, здатний взаємодіяти 3 гетероциклічними кетеновими аміналями 3 утворенням амідиній броміду. Тому виходи пірол конденсованих гетероциклів $є$ помірними 41-50\%. Однак реакція сильно залежить від розміру гетероциклу. П'ятичленні гетероциклічні кетенаміналі піддаються швидкій реакції $з$ а-бромоацетофеноном при кип'ятінні в етанолі і 1,4-діоксані, що призводить до отримання продукту з помірними виходами, тоді як 
шестичленні аналоги є менш реакційноздатними в тих же умовах і лише після тривалого кип'ятіння в 1,4-діоксані утворюють продукти 3 низькими виходами. Тому авторами [4] була здійснена спроба покращити вихід реакції за допомогою додавання сполук з основними властивостями, таких як триетиламін, піридин та натрій карбонат, проте це не призвело до бажаного результату.

В сучасному світі для інтенсифікації і збільшення виходів хімічних реакції, які дають важливі продукти використовують різні підходи. Одним зі яких $є$ використання ультразвукового випромінювання в органічному синтезі.

Ультразвук - це акустичні коливання, що мають частоту вище межі, яку може сприйняти людське вухо. До них належать акустичні хвилі 3 частотою вище 20000 Гц. Цей тип випромінювання може впливати на хімічні та фізико-хімічні процеси наступним чином: ініціювати деякі хімічні реакції, впливати на швидкість і напрям хімічної реакції, емульгувати рідини, що не змішуються, диспергувати тверді тіла, вилучати гази 3 рідин і т.д. Вплив ультразвуку на вищеперелічені процеси пов'язаний з утворенням в рідині порожнин, заповнених газом (кавітаційних бульбашок) під впливом акустичних хвиль - кавітацією.

Запропоновано декілька механізмів, які пояснюють вплив ультразвуку на хімічні реакції. За тепловою теорією, в момент схлопування кавітаційних бульбашок всередині температура становить 10000 К і тиск 103 МПа, що призводить до термічної дисоціації хімічних сполук на радикали. Радикали частково рекомбінують і реагують 3 розчиненими речовинами за непрямим механізмом. Незалежно від складу розчину хімізм процесів при впливі ультразвуком визначають два компонента проникаючі в порожнину розчинені гази і пари води.

Але з часом було виявлено багато експериментальних чинників, які суперечать тепловій теорії i iï модифікаціям. Найбільш точно відповідає експериментальним даним електрична теорія. В цій теорії розглядається подвійний електричний шар на поверхні кавітаційної бульбашки. А під час іiі схлопування утворюється некомпенсований електричний заряд, через який молекули можуть розпадатись на радикали або передавати енергію збудження іншим молекулам. Таким чином, процеси, що відбуваються в кавітаційній бульбашці зводяться до збудження і іонізації молекул.

Для пояснення хімічних ефектів у неводних розчинах розглядаються дві гіпотези. За першою, виникнення електричних розрядів в процесі кавітації, виділення енергії в локальних мікроскопічних областях системи і подальше швидке охолодження реагентів можуть привести до різкого локального підвищення швидкості хімічних реакцій. При цьому не встигає здійснюватися 142 
розкладання цільових продуктів, i селективність процесу зростає, оскільки вся рідина залишається практично холодною. За другою, при наявності в розчині твердої фази, відбувається ультразвукова чистка поверхні від забруднень, плівок, також $\epsilon$ місце відриву дрібних частинок від поверхні під впливом ультразвуку. Це веде до збільшення швидкості реакції.

Тому нами було вирішено дослідити вплив ультразвуку на швидкість реакції алкілювання кетенаміналей. Реакцію проводили між кетенаміналями: 2-(імідазоліден-2-іліден)-1-фенілетан-1-ону та 2-(імідазоліден-2-іліден)-1-n-толілетан-1-ону та бромокетонами: 2-бромо1-(4-нітрофеніл)-етан-1-оном і 2-бромо-1-(4'-бромофеніл)-етан-1-оном в ацетонітрилі із застосуванням ультразвукового диспергатора. Протягом 40 хвилин суміш піддавали впливу ультразвукових хвиль. Контроль перебігу реакції здійснювали за допомогою тонкошарової хроматографії, яка показала утворення в реакційній суміші продукту, але і присутність вихідних сполук, що свідчило про неповний перебіг реакції. Збільшення часу перебігу реакції на результат суттєво не вплинуло і виділити цільовий продукт у чистому вигляді із задовільними виходами не вдалося. Це дозволяє зробити висновок, що використання ультразвукового випромінювання не є раціональним для даного синтезу.

Проте, зважаючи на високу реакційну здатність гетероциклічних кетенових аміналей та біологічну активність їх похідних, подальші дослідження методів синтезу та шляхів модифікації цих сполук $\epsilon$ важливими.

\section{Література:}

1. Huang Z. T., Wang M. X. Heterocyclic Ketene Aminals: Scaffolds for Heterocycle Molecular Diversity. EurJOC. 1994. № 2. P. 1233-1262.

2. Peng H. Y. Recent Developments in the Heterocyclic Ketene AminalBased Synthesis of Heterocycles. Research on Chemical Intermediates. 2016. № 6. P. 78.

3. Huang Z.T., Liu Z.R. Alkylation of Heterocyclic Ketene Aminals with Benzyl Chloride and Ethyl Bromoacetate. Synthesis of Heterobicycles Containing y-Lactam-Fused Diazaheterocycles. Chem.Ber. 1989. № 1. P. 95-100.

4. Nie X. P., Wang M. X., Huang Z. T. Reaction of Heterocyclic Ketene Aminals with $\alpha$-Bromoketones: A Convenient Synthesis of Pyrrole-Fused 1,3-Diazaheterocycles. Synthesis. 2000(10) P. 1439-1443. 